\title{
FORESTS IN THE CZECH PUBLIC DISCOURSE
}

\author{
JANA STACHOVÁ
}

Ctiboř 24, Častrov, 39468, e-mail: jana.stachova@soc.cas.cz

Received: $24^{\text {th }}$ October 2018, Accepted: $29^{\text {th }}$ November 2018

\begin{abstract}
Forests are being increasingly studied within the framework of social sciences, especially in relation to environmental problems and global climate change. This article deals with the perception of Czech forests and their management at two basic levels: at the level of sociological analysis of in-depth interviews with experts in the field of forestry and at the level of public opinion research. The main aim of this study was to describe the attitudes of professionals and the general public towards forests and forestry, especially with regard to climate change. Qualitative analysis of interviews with professionals discerned two main categories of opinion: ecological realism and social constructionism. The results of the study show that the Czech public, in agreement with ecological realists, considers it highly important to preserve and support the non-productive environmental functions of forests. The public also prefers close-to-nature forest management practices. Czech Republic is witnessing a fundamental shift in the mindset about forests. Although the public still expects forests to retain their production function, it perceives their environmental functions as increasingly important.
\end{abstract}

Keywords: forest functions, forest management, public opinion, professionals' opinions

\section{INTRODUCTION}

The term 'landscape' has become a crucial scientific concept in challenging global climate change and its repercussions for society. In this context, as well as in the context of sustainability, there is a strong need for social science research of landscape issues. The landscape represents a broad multidisciplinary concept used to study environmental issues (Greider \& Garkovich, 1994; Fry, 2001; Tress \& Tress, 2001; Axelsson, 2010; Miklós \& Špinerová, 2010; Naveh, 2010,). Studying relationship between the society and the landscape, or certain parts of the landscape such as forests, can significantly contribute to analyses of the impacts of climate change on society.

Czech forests have recently faced major problems attributable to climate change. Although the area of forests in the country is increasing ${ }^{1}$, forest vegetation in many places suffers from drought and high temperatures (Buček \& Vlčková, 2009; Fanta \& Petř́k, 2018). In the forestry sector, there is a hot expert discussion on how to respond to these changes in order to maintain forests for future generations. Apart from this discussion within the field of forestry, it is also possible to look at the problem of forests from the perspective of social sciences. Forests are being increasingly studied within the framework of social

\footnotetext{
${ }^{1}$ Forests represent $34 \%$ of total area of the Czech Republic.
} 
sciences, especially in relation to environmental problems and global climate change; in Czech Republic, however, very little sociological research concerning forests and forestry has been carried out, apart from a few studies (Krajhanzl et al., 2015; Dušek et al., 2017; Př́hoda \& Malčánková, 2017). The Czech literature on the matter mainly consists of studies focused on how people relate to nature or the landscape in general (Librová, 1984; Černoušek 1992; Krajhanzl, 2014; Vysušil, 2005). Empirical studies on how both the professional and general public relates to forests are mainly performed in countries with large areas of forest ecosystems, such as North America, Australia or Northern Europe, and likewise in countries with unique forest ecosystems such as mountain forests (Shindler et al., 2002; Kozak et al, 2008; Web et al., 2008; Lindkvust et al., 2012; Pastorella et al., 2016).

In the twentieth century, humans had begun to dominate ecosystems in an unprecedented way. To find out what is happenings to ecosystems, it is necessary to understand the social, economic and culture beliefs that drive human actions (Vitousek et al., 1997). It is also important to understand the varied services that forest ecosystems can provide: from the goods and services demanded by society to the regulation of climatic and hydrological cycles and to the biodiversity and genetic resources contained within them (Patel et al., 1999, Hajjar et al., 2014).

Every piece of objective knowledge about the world is conditioned historically and culturally, so it is subject to questioning. Analogously, contemporary environmental problems are subject to various social interpretations. It seems that there are several distinct and incompatible assertions and beliefs concerning the situations and problems faced by society (Thompson, 1991). Each of these problems (e.g. climate change or forest health) can be simultaneously interpreted in different ways.

How people relate to nature and the environment is the core topic of environmental sociology. The main goal of this field is not to merely describe problems, but to analyse the dynamic social processes of definition, negotiation and legitimation. The questions posed by this discipline are: Who in the public space articulates the existence of environmental problems, who stands against these claims, and what is the social and political context of this process. One of the fundamental questions asked in this discipline is whether environmental issues are an objective reality or a social construct based on subjective perception (Hannigan, 2006). The simplified premise behind social constructionism is that no condition is a social problem unless a group with some minimum power considers it one. Environmental sociology therefore focuses on the claims-making activities of these groups, asking not whether their claims are valid, but whether they are viable in the public arena (Parkins, 1999).

In accordance with the assumed dichotomy between objective reality and social constructions, we can find two primary understandings of forests in the literature. First, the utilitarian view, similar to anthropocentrism, in which the health of a forest is measured by its ability to provide material benefit to humans or to meet specific management objectives. The emphasis is on the instrumental importance of the environment for achieving human goals. The ecosystem view (i.e. the biocentric value orientation or the nature-centred perspective) places human uses and values in an ecological context and emphasizes the primacy of goals such as environmental protection, preservation and maintenance or improvement of ecosystem health and integrity. This approach uses information on historical ecological patterns and processes as a template for measuring forest health (Abrams et al., 2005).

These views correspond with two different ideological viewpoints regarding desirable forest practices and conditions: environmentalism on the one hand and resource extraction interests on the other (Abrams et al., 2005; Web et al. 2008). Forests are socio-ecological 
systems that have developed over time through the interplay of natural and social forces. The views, attitudes and interests held and expressed by stakeholders are significant components of social forces and exert a significant influence on choices made. Varying views, attitudes and interests among different stakeholders may give rise to conflict concerning the use and management of forests (Abrams et al., 2005).

There is an essential belief in the predominant relevance of environmental values, a strong recognition of the need to address climate change, and evidence suggesting that quality of life indicators are of high importance and not determined primarily by economics (Kozak et al., 2008). People's attitudes towards forests are the result of their emotional and behavioural experience in relation to their exposure to different forests, cultural heritage and the present socio-demographic context. Different people therefore differently appreciate the ecological, aesthetic and recreational values of forests as well as their perceived productive (financial) value (Lindkvust et al., 2008).

Sociological research can be benefit forestry in many ways. Sociology has a role at both ends of the policy-making process. It can provide basic information useful in defining parameters of key social problems or it can help in policy analysis. Although sociology has only relatively recently started researching topics specific to the forest sector, it can address some of the general issues faced by society today. One of these issues is the general concern for sustainable forest management (Parkins, 1999). Because of the importance of including public values in decision making, there is a need to examine the public's opinions about forests, especially pertaining to their health (Abrams et al., 2005). The interests and demands of the public will ultimately affect how forest policies are implemented and accepted. The public's attitude towards forestry is important mostly due to its indirect impact on decision making processes (Shindler et al., 2002; Kavaliauskas et al., 2015).

Recent empirical studies carried out in other countries support a relative decline in the importance assigned to the economic value of forests by the general public and an increase in the perception of non-economic values, especially ecosystem protection and amenities (Tarrant et al., 2003; Abrams et al., 2005; Kozak et al., 2008). The public favours a balance between environmental protection and economic development in public and private forests, but with a very strong tilt in favour of the environment. The attitudes of the public towards forests have changed since the late 1980s from a commodity-oriented perspective to a more inclusive (commodity and non-commodity) orientation. We can now observe more pro-environmental values and attitudes. Since the late 1960s, a "new environmental paradigm" emphasizing the sustainable development of, and harmony with, a finite supply of natural resources has slowly been replacing the "dominant social paradigm" associated with the economic development of, and human control over, natural resources. At the core of this paradigm shift are changing public values and attitudes on how people should relate to forests and the natural environment (Tarrant et al., 2003).

The implication of this for forestry is that a more complete understanding of stakeholders' values and attitudes is integral to achieving acceptable decisions about how resources are managed. Many studies have argued that the key to effective management of natural resources is an understanding of people's relationships towards the environment. More generally, an understanding of the public's attitudes and values concerning forests, as well as of changes associated with these attitudes and values, equips forest managers to deal with potential conflict, set policies and goals, and define broad strategies (Tarrant et al., 2003). 


\section{RESEARCH METHODS}

The perception of Czech forests and their management is the subject of this study at two basic levels: At the level of sociological analysis of in-depth interviews with experts in the field of forestry and at the level of public opinion research. The comparison of these two points of view is important for the understanding of how the society's approach to forests changes over time (Patel et al., 1999; Petuccoa et al., 2013).

Data for the public opinion survey were collected by quota selection ${ }^{2}$ (quota characters: NUTS 3, size of municipality, sex, age and education) from a sample of the Czech population aged 15 and over in June 2017. The size of the selection was 1,200, and the total number of was 983 . The sociological data file was analysed using SPSS IBM ${ }^{3}$.

As part of the qualitative sociological study, a case study of views concerning the quality and management of Czech forests with respect to climate change was carried out. This case study is based on data from fourteen in-depth face to face interviews made in June 2017 with experts in the field of forestry (five foresters, five researchers, two governmental officials, one representative of the timber industry and one representative of environmental organization). Experts represent different regions of the Czech Republic and public as well as the private sector. The data were processed by standard tools of sociological qualitative analysis. The data were acquired from literally transcribed interviews by assigning codes to their key points and searching for relationships among them. The encoding and processing of qualitative data was carried out using MaxQDA ${ }^{4}$.

\section{RESULTS AND DISCUSSION}

\section{Public opinion on forests}

The Czech public perceives the problem of climate change in relation to its threat to forests as real, and $53 \%$ of believe that forests in Czech Republic are not resistant to the ongoing climate change whereas $35 \%$ of them think that they are. That Czech forests are not able to withstand climate change is especially thought by people from municipalities with up to 800 inhabitants, left-wing supporters and people dissatisfied with life and the political situation. By contrast, people that perceive their standard of living to be very good and those that have expressed their satisfaction with life and the political situation tend to think that forests are definitely resistant to climate change. It seems that the perception of the resistance of Czech forests is related to the respondent's general attitude to life.

As regards the different functions of forests, the data show that the public mainly emphasizes non-productive (environmental) functions of forests. The respondents consider very important the following functions: climate protection (68\% of respondents), water protection $(66 \%)$, soil protection $(63 \%)$, biodiversity protection $(55 \%)$, aesthetic function $(52 \%)$, landscape-forming function $(51 \%)$, production of forest fruits and mushrooms

\footnotetext{
${ }^{2}$ Quota selection is a method for selecting survey participants - respondents. The sample is composed to match the distribution of selected characteristics (quotas) in the Czech population, so the percentage occurrence of groups in the sample (NUTS 3, size of municipality, age, education, sex) corresponds to the general population. Personal interviews (using questionnaires) with the respondents were used to collect the data.

${ }^{3}$ Statistical Package for the Social Sciences

${ }^{4}$ Professional Software for Qualitative \& Mixed Methods Research
} 
(43\%), recreation function (37\%), and wood production (36\%). It therefore seems that the public does not regard the function of wood production as highly important.

When the respondents were asked to select only the three most important functions, they tended to include wood production (see Fig. 1). The majority selected the function of biodiversity protection as the most important, then the functions of climate protection and wood production, followed by the protection of soil against erosion and water protection. More educated people often selected the production function. These results indicate that the Czech public perceives forests in the broad context of environmental protection. Although the public is aware of the importance of the production functions of forests, environmental functions are more important for the majority of respondents.

\section{Fig 1: Importance of forest functions}

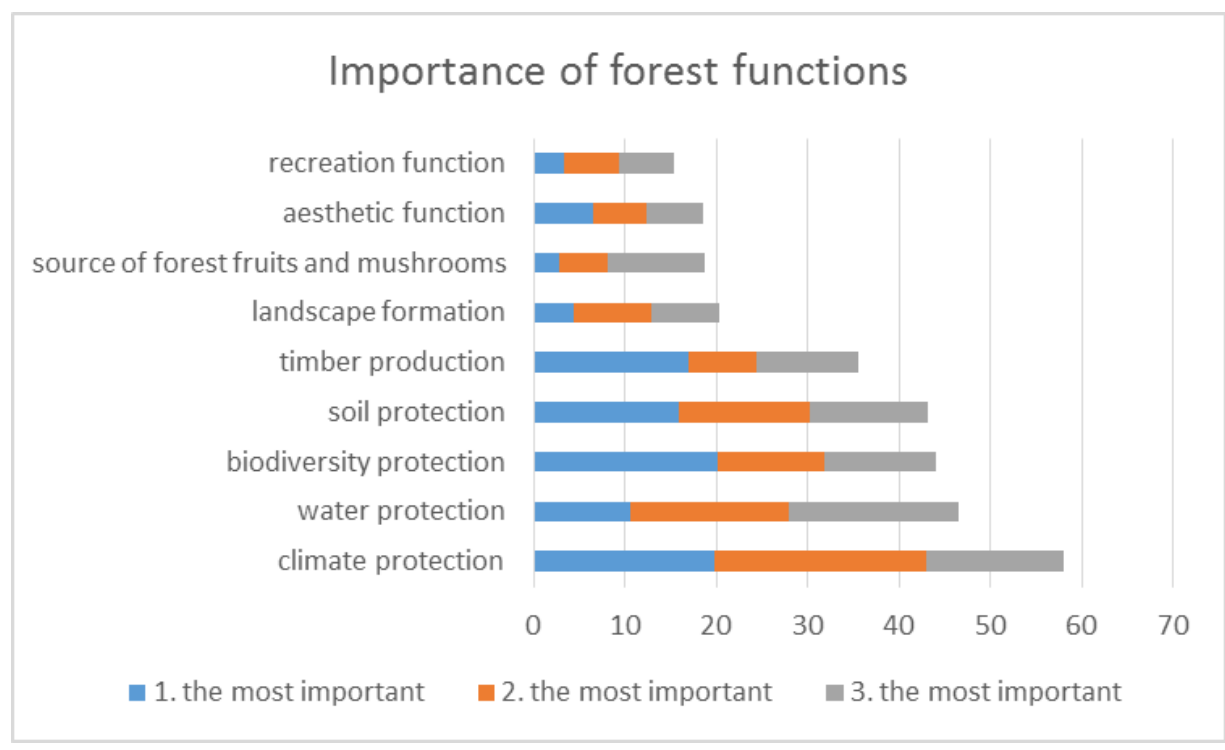

With regard to the current state of forests, $77 \%$ of respondents believe the polluted environment has a negative impact on Czech forests, $70 \%$ perceive clear cutting negatively, $48 \%$ opine that the overpopulation of game has a negative effect on forests, and $45 \%$ believe that monocultures have an adverse effect on forests in Czech Republic. Only $39 \%$ of respondents consider unfavourable the fact that no old trees are present in forests.

In general, the public, especially more educated people, prefers forest management that results in close-to-nature forest. Most people believe that the return of wild carnivorous animals to Czech forests is desirable ( $78 \%$ ). The same share of respondents also believe that cutting of small groups of trees or individual trees, as opposed to the creation of large clearings, increases the resistance of forests to climate change. Fifty-four per cent of them consider it necessary to reduce game stocks in Czech forests. Seventy-six per cent of respondents believe that planting of introduced tree species imported from other continents may have a bad impact on forests. Seventy-five per cent of respondents are of the opinion that the management of forests predominantly focuses on produce timber without sufficient respect for the environment. These results correspond with the conclusions of similar European studies. For example, one survey conducted in Italy and Bosnia-Herzegovina shows that more than $60 \%$ of respondents prefer unmanaged forests and close-to-nature managed forests (Pastorella et al., 2016). Most people do not like extensive forest clearings 
(65\%), and the vast majority of respondents also do not like asphalt bicycle paths in forests (77\%). This constitutes evidence that the public is not in favour of intensive forest management or of intensive recreational use of forests.

The results also show a paradox in the perception of wilderness in the Czech landscape. Although $85 \%$ of respondents said that they liked places with wild nature in forests, they also tend not to like dead and fallen trees $(73 \%)$. This contradiction may mean that people do not have a very precise idea of the concept of wilderness or wild nature. Awareness and information campaigns on the multifunctionality of forests might lead citizens to improve their knowledge about the roles of all components of forest ecosystems (Pastorella et al., 2016).

\section{Fig. 2: Things liked or disliked in forests}

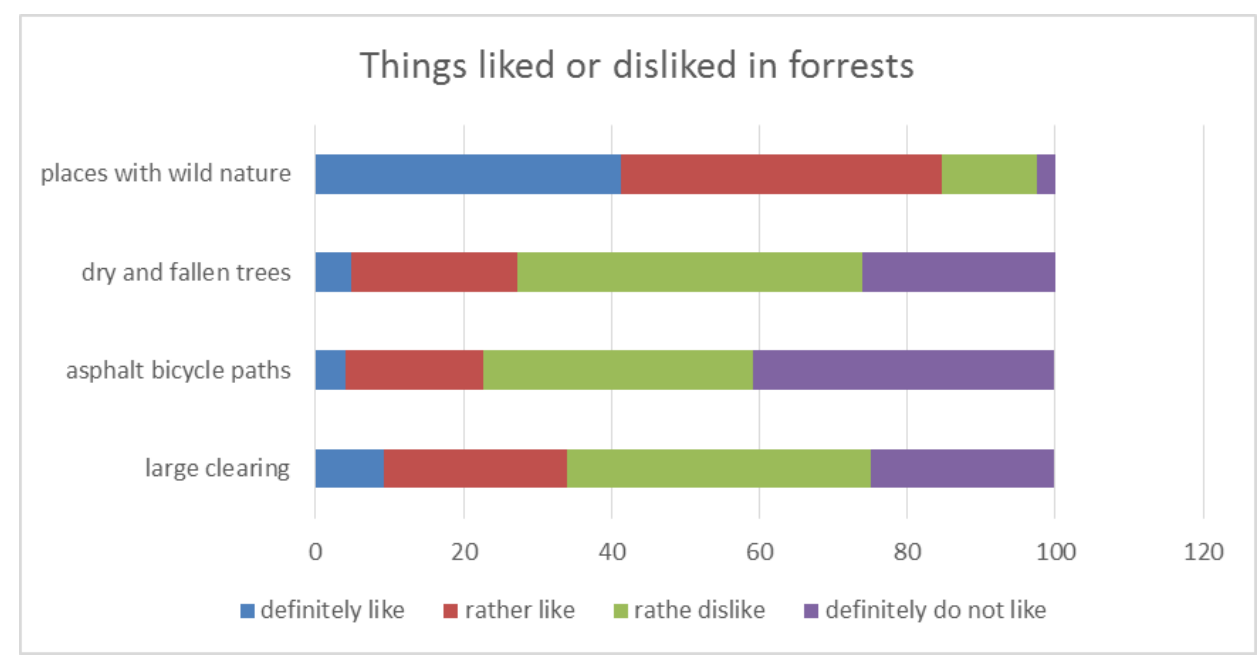

Although from the above results we can conclude that people prefer the close-to-nature conception of forests, only less than $14 \%$ of all respondents know about the existence of Forest Stewardship Council certificates (which designate products made of wood obtained from close-to-nature forest management). Moreover, only $55 \%$ of this small group of people consider FCS certificates in their purchasing decisions.

\section{Professionals' opinions on forests}

Analysis of the data from the interviews shows that two of the aforesaid basic approaches to knowledge about Czech forests emerge. The first is the ecosystem view, referred to in this study as 'ecological realism'. Those that hold this view do not doubt that Czech forests objectively face problems and at the same time have a clear idea how to deal with them (by bringing about a significant change to the current style of forest and landscape management). The second, utilitarian approach, which can be called 'social constructivism', is characterized by a relativistic attitude to scientific knowledge and represents the belief that the current state of knowledge of Czech forests does not give clear guidance on how they should be treated. According to the proponents of this view, the assessment of the quality of forests depends on the expectations of the individual or society.

In the statements of Czech experts, it is possible to discern three main groups of thematic areas representing a range of interpretations of forest problems - from consensual 
interpretations, through complementary or different interpretations, to conflicting interpretations.

\section{Consensual interpretations of forestry issues}

What unites experts across the spectrum of opinion is the fundamental negative impact of high numbers of game in Czech forests, which not only clearly affect forest rejuvenation but also causes significant economic losses. Overpopulation of game means more expensive reforestation and sometimes even completely eliminates natural regeneration. The reasons for this extreme situation can be found, on the one hand, in insufficient political will at high levels of the state administration to solve this problem and, on the other, in the unwillingness of game managers to alter their patterns of action. Experts mostly agree with the return of wild carnivorous animals into Czech forests, even though they admit that predators will not have a substantial effect on the situation.

Another consensual point in the debate on forest management is how forestry affects the development of the Czech countryside and vice versa. The link between the forestry economy and the rural population (or the countryside in general) has greatly diminished in Czech republic. It is maintained only by smaller forest owners with close ties to their property. The detachment of people from forests is especially apparent in state forests and its wood supply chain. Most job opportunities offered by the forestry sector fall into the category of low-skilled labour for low wages, often under difficult conditions and in many cases needed only seasonally. Czech workers are losing interest in working in forests, and so are foreign workers, who are highly sought after by industrial employers. Investments in new technologies also reduce job opportunities in forestry.

As concerns the planting of non-native tree species, there is a consensus across the spectrum of opinion that it does not constitute a significant problem, provided that they are not planted uncontrolledly or on a massive scale. The definition of non-nativeness, especially with regard to longer time frames, is a topic of discussion, but this discourse is not a source of any fundamental conflict in the field. On the contrary, in connection with the effects of climate change on Czech forests, some point to the possible need for the planting of non-native species.

The need for the rehabilitation of foresters in our society is obvious to both opinion groups. In contemporary society, forestry-related occupations not only have no prestige, but the public awareness about the content of these occupations is low. Foresters often call themselves a "closed group" that slowly adapts to social change. Moreover, experts also often agree that foresters are not sufficiently enlightened on environmental issues and not great at communication. Historically, foresters have relied on technical and economic principles, but new demands are being placed on forestry in relation to the strong emphasis on non-production and environmental functions of forests. Whereas constructionists would prefer to maintain the traditional way of forest management, modified to reflect climate change, realists would rather replace it with a entirely new concept. Because contemporary forestry education reflects these views, supporters of the need for a new approach see certain hope in generational exchange.

\section{Different interpretations of forestry issues}

The quality of forests and the closely related need to change the style of their management is a topic on which the distribution of opinion is beginning to shape. Experts differ in what they consider indicators of forest health, be it the total area of forests, timber resources, the share of mixed forests or broadleaved trees, the share of salvage cutting, defoliation, soil conditions, etc. Whereas advocates of the traditional approach (i.e. 'constructionists') opine 
that the state of Czech forests is improving, based on the increasing area of forests and increasing share of broadleaved trees, critics of the current situation (i.e. 'realists') speak about the increasing share of salvage cutting, poor soil conditions or a still far too allochthonous tree species composition.

There is a fundamental consensus across the spectrum of opinion that, due to the clear evidence for climate change, there is a need to alter the way forests are managed in order to eliminate its negative impacts. However, the professional public disagrees on the form of this change. While supporters of traditional forms of forestry often refer to history, that is, to the beginnings of forestry and to economic reasons behind the planting of spruce, others view history as the cause of the current critical situation and emphasize the need to change these historically rooted approaches.

The defence of the status quo of Czech forestry (i.e. 'constructivism') stems from historical tradition and economic aspects, namely the fundamental need for economic profit from wood. Forests for production have been established to provide the greatest possible profit from wood and, according to the adherents of this view, the task of foresters is to take care of them responsibly. According to 'constructionists', this profit is most effectively achieved by the forest model of the age classes. They refer to this model as either a 'genius mathematical model" or a "wood factory". They are convinced that the utilization of forests is always influenced by social demand and that humans have always influenced the face of forests, so there is no reason to be afraid of this influence even today. Proponents of the traditional forestry approach also often refer to "common sense" when turning to new ways of forest management, and they do not reject new approaches to forestry such as a return to a more close-to nature tree species composition or taking advantage of natural processes. They, however, differ from the realists in the extent to which they would utilize these management tools. They often point to the detachment of common people from forests and forestry. What people expect from forests varies depending on their social standing, as poorer people living in the countryside have different expectations than the middle class in cities.

Constructionists argue that forest management is becoming more flexible and varied, and that the share of natural regeneration is rising, so invoking catastrophic scenarios of forest destruction has no merit because nature will help itself in the end. For them, efforts to bring about radical change to Czech forestry is an ideological struggle for which financial incentives can be sought.

The 'ecological realism' approach in Czech forestry is legitimized by the objective existence of environmental risks, which has been proved by scientific knowledge that was not available at the time when forestry emerged as a discipline. Its proponents hold the opinion that forestry is holding on to patterns that are not suitable in the current situation. This can have negative consequences not only for forests, but for the landscape and the environment in general. Forestry had until recently been able to count on consistent natural conditions. However, the changes that are currently taking place are happening much faster than in the past, and it is difficult for foresters to respond to them. According to the 'realists, the correct response to these changes would be to radically change the tree species composition to make it suit local conditions5.More emphasis should also be placed on natural processes and natural regeneration, which can improve the stability of forests. The legislation (namely the forest act) largely hinders alternative forest management because it is based on the forest model of age classes. Although foresters have adopted the vocabulary of natural science disciplines and some basic principles of nature conservation (e.g. sustainability and

\footnotetext{
5 There are differences even among realists as to what share of spruce is limiting.
} 
biodiversity), according to the 'realists', there is still a degree of resistance to new scientific knowledge in forestry.

Although "constructionists" also rely on scientific arguments, they very often question their relevance and point to the absence of significant scientific results. They say that it will not be easy to adapt to climate change, because it is not known how the situation will develop and how exactly we should respond. Furthermore, they say that there are no straightforward solutions, for example that it is not easy to precisely determine the target, let alone the natural, composition of tree species. They also point out that natural regeneration should be preferred only in protected areas because natural renewal does not always produce a desirable type of forest. Constructionists admit the need for change; however, within the current legislative framework, this change should be done slowly and not 'hysterically'.

Economic profit from forests and responsibility towards future generations are arguments both for adhering to the traditional model of age classes and for turning to selective and shelterwood systems of forest management. 'Constructionists' argue that relying on natural regeneration and selective systems is irresponsible towards future generations, which may not have enough timber resources. They opine that the economic benefit of these alternative forestry systems is difficult to estimate and that a more significant share of broadleaved forests could pose a problem for future generations because the largest economic benefit comes from spruce. 'Realists', on the other hand, claim that if the Czech forest management system does not change in the near future, there will be no forests to keep for future generations at all. Everyone then agrees that the selective system of forest management places much greater demands on the expert erudition of foresters, especially when it comes to the early recognition of processes taking place in forests. Moreover, constructionists see selective and shelterwood systems as economically profitable in most parts of the Czech Republic.

Constructionists argue that the image of what forests should look like has always depended on the specific needs of society. Carrying this further, they argue that there is no ideal image of what a forest developing without human influence should look like and that we do not know how forests naturally behave because there are no natural forests to refer to. Such opinions are often voiced in disputes about what amount of dead wood is desirable or what composition of species is natural. Whereas the 'constructionists' claim that there is no broadly accepted definition and no clear requirement, realists are convinced that these issues are scientifically well explored and that foresters can draw upon this scientific knowledge.

\section{Conflictual interpretations of forestry issues}

The forest act is a subject of frequent disputes among forestry experts. According to constructionists, who support the traditional approach, forests are managed properly, responsibly and sustainably while at the same time he law does not obstruct alternative management styles. For realists, by contrast, the Czech legislation is strongly binding and does not give forest owners the possibility to freely and without any obstacles chose alternative forest management practices, because all management tools are designed to only suit the traditional model of age classes. Realists also assert that the Czech legislation does not sufficiently reflect current scientific knowledge on forest ecosystems and that it insufficiently takes account of the need to adapt to climate change. The attitude towards the legislation is related to opinions on forest certification. Those that find the Czech legislation to be of high quality (i.e. constructionists) regard the introduction of a new certification scheme for state forests (i.e. the Forest Stewardship Council) as redundant. Realists, by contrast, see the FSC certification as an opportunity to transform Czech forestry so that it is better adapted to climate change. Opponents of the certification perceive the FSC as a tool for 
the promotion of environmental ideology and as a significant onus on forest owners. The PEFC, according to constructionists, takes greater account of the needs of forest owners while adhering to the principle of sustainability of forest management. We can compare these findings with the conclusions of a study of these two systems: If applied consistently, the FSC standard can substantially contribute to the sustainable management of forests. The PEFC may contribute to some improvement in certain areas, but in most of the key sustainability criteria it does not because of its low transparency and high complexity (Hošek et al., 2018).

Another conflicting topic is the area of environmental protection, where there is a clash between the paradigms of forestry and natural science. Mutual misunderstandings occur in different domains of forestry: between practical forestry and conservation activities and at various levels of the state administration, as well as between scientific and forestry institutions. At the local level, however, cooperation works better and more constructively, and representatives of environmental protection and foresters or forest owners are able to negotiate with each other without any major problems. The often see a fundamental reason for the contradictions at the highest levels of the state administration, for example at ministries.

According to the constructionists, foresters are knowledgeable of the results of scientific research. They also point to a lack of knowledge of forestry as a field among natural scientists. Constructionists interpret this conflict as a power struggle over who will have the key influence - representatives of state environmental protection bodies or foresters. Realists, by contrast, say that foresters do not take seriously the arguments of natural scientists and criticize foresters for their unwillingness to abandon the outdated forestry paradigm. The considerably technocratic inclination of Czech foresters causes disagreements with natural scientists. Even supporters of a forestry reform admit that it is very difficult for practical foresters to adopt changes when their lifelong work and convictions are being questioned.

Constructionists often point to the social background of the dispute between foresters and conservationists, according to which people in general, and especially the middle class, have lost direct contact with nature and the sense of its use by humans. That is why the public has a tendency to idealize forests and not to perceive them in economic and ownership terms. Public opinion is influenced by ecological movements, and foresters are unable to defend their arguments in the public media space. This situation is well illustrated by attitudes towards wilderness, as people that do not sufficiently understand this concept, claim to appreciate wild forests yet expect something entirely different; they enjoy going to forests to pick mushrooms and blueberries without having to climb over fallen trees.

\section{CONCLUSION}

Our conclusions to some extent concur with Abrams's statement that the professional public is far more polarized than the lay public as far as forests are concerned (Abrams et al., 2005). The public, in agreement with ecological realists, considers it highly important to preserve and support the non-productive environmental functions of forests. The public also prefers close-to-nature forest management practices. As in other countries, in Czech Republic we are witnessing a fundamental shift in the approach to forests. Although it is still expected by the public that forests retain their production function, it perceives their environmental functions as increasingly important. From the point of view of environmental sociology, it can be said that groups promoting the urgency of environmental problems are successful in the public discourse. Although constructionists take this shift into account, they 
still regard forests primarily as a human creation whose main task is to generate economic profit, which is best ensured by the age class model. They argue that realists overestimate the potential of "ecological rationality" and neglect the cultural and social roots of forest management. Despite this fundamental dispute, there is a whole range of particular management issues on which experts from both sides agree or can find a middle ground, for example game overpopulation. These topics can be seen as a basis for further dialogue on the future of Czech forests.

\section{ACKNOWLEDGEMENTS}

Author would like to thank Frederick Rooks for the text proofreading.

The writing of this paper was supported by the project Strategy AV21, programme Diversity and Health of Ecosystems.

\section{REFERENCES}

Abrams, J., Kelly E., Shindler, B., Wilton, J. (2005). Value Orientation and Forest Management: The Forest Health Debate. Environmental Management. 36 (4), 495-505.

Axelsson, R. (2010). Integrative research and transdisciplinary knowledge production: a review of barriers and bridges. Journal of Landscape Ecology 3 (2) 14-40.

Buček, A., Vlčková V. (2009). Možný vliv globálních změn klimatu na vegetační stupně 1990-2030. Mapy 1: 2,000.000. Atlas krajiny ČR, 7. odd. MŽP - VÚKOZ, Praha.

Černoušek, M. (1992). Psychologie životního prostředí. Praha: Karolinum.

Dušek, D., Kacálek, D., Novák, J., Slodičák, M. (2017). Vnímání rekreačních potřeb veřejností - dotazníková studie v příměstských lesích Ostravy. Zprávy lesnického výzkumu. 62 (3). 174-181.

Fanta, J., Petrrík P. (2018) Forests and Climate Change in Czechia: an appeal to responsibility. Journal of Landscape Ecology 11(3): 5-19.

Fry, G. L.S. (2001). Multifunctional landscapes- towards transdisciplinary research. Landscape and urban Planning 57 (3-4), 159-168.

Greider, T., Garkovich, L. (1994). Landscapes: The Social Construction of Nature and the Enviroment. Rural Sociology 59 (1), 1-24.

Hajjar, R., McGuigan, E., Moshofsky, M., Kozak, R.A. (2014). Opinions on strategies for forest adaptation to future climate conditions in western Canada: surveys of the general public and leaders of forest-dependent communities. Canadian Journal of Forest Research. 44. $1525-1533$.

Hannigan, J.A. (2006). Environmental sociology. New York and London: Routledge

Hošek, J. (2018). Porovnání vybraných environmentálnich aspektů certifikačních systémi̊ FSC a PEFC v ČR $s$ di̊razem na pưdu, vodni zdroje a biotu lesnich ekosystémů. Depon in: Institute of Botany. The Czech Academy of Sciences.

Kavaliauskas, M., Linkevičius, E., Jonikavičiu, D., Kokankaité, K. (2015). Public opinion analysis on state forest management: Study Area in Kaišiadorys municipality. Proceedings of the 7th International Scientific Conference Rural Development 2015. DOI: http://doi.org/10.15544/RD.2015.043

Kozak R.A., Spetic, W.C., Harshaw, H.W., Maness, T.C., Sheppard, S.R.J. (2008). Public priorities for sustainable forest management in six forest dependent communities of British 
Columbia. Canadian Journal of Forest Research. 38(12). 3071-3084.

Krajhanzl, J., Skalík, J., Špaček, O., Chabada, T., Čada, K., Lechnerová, Z., Svobodová, R. (2015). Ochrana divoké př́rody očima veřejnosti. Brno: FSS MU.

Krajhanzl, J. (2014). Psychologie vztahu k prírodě a životnímu prostředí. Brno: MUNI press. Librová, H. (1984). Vztah obyvatel ke krajině. Spisy FF 19(1). 527-534.

Lindkvust, A., Mineur, E., Nordulnd, A., Nordlind, C., Olsson, O., SandsrŐm, C., Westin, K., Keskitalo, E. C. H. (2012). Attitudes on intensive forestry. An investigation into perceptions of increased production requirements in Swedish forestry. Scandinavian Journal of Forest Research. 27 (5). 438-448.

Miklós, L., Špinerová, A. (2010). Approaches and compromises in the concept of landscape. Journal of Landscape Ecology 3 (2) 7-13.

Naveh, Z. (2010 Ecosystem and landscapes - a critical comparative appraisal. Journal of Landscape Ecology 3 (1) 64-81.

Parkins, J. (1999). Contributions of sociology to forest management and policy development. The Forestry Chronicle. 75(4). 643-645.

Pastorella, F., Avdagić, A., Čabaravdić, A., Mraković, A., Osmanović, M., Paletto, A. (2016). Tourists' perception of deadwood in mountain forests. Anals of Forest Research. 59(2). 311-326.

Patel, A., Rapport, D. J., Vanderlinden, L., Eyles, J. (1999). Forests and societal values: comparing scientific and public perception of forest health. The Environmentalist. 19 (3). 239-249.

Petuccoa, C., Skovsgaarda, J.P., Søndergaard, J. F. (2013). Recreational preferences depending on thinning practice in young even-aged stands of pedunculate oak (Quercus robur L.): comparing the opinions of forest and landscape experts and the general population of Denmark. Scandinavian Journal of Forest Research. 28(7). 668-676,

Př́íhoda, J., Malčánková, T. (2017). Co si myslí návštěvníci lesa o lesích a lesnictví. Lesnická práce. 12. 38-41.

Shindler, B., Wilton, J., Wright, A. (2002). A social assessment of ecosystem health: Public perspectives on Pacific Northwest forests. Department of Forest Resources, Oregon State University, Corvallis, Oregon.

Tarrant, M. A. Cordell, K.H., Green, G. T. (2003). PVF: A scale to measure public values of forests. Journal of Forestry. 101(6). 24-30.

Thompson, J. B. (1991). Ideology and Modern Culture. Stanford: Stanford University Press.

Tress, B. \& Tress, G. (2001). Capitalising on multiplicity: a transdisciplinary systems approach to landscape research, Bridging human and natural sciences in landscape research. Landscape and urban Planning 57 (3-4), 143-157.

Vitousek, P.M., Mooney, H.A., Lubchenco J., Melillo, J.M. (1997). Human Domination of Earth's Ecosystems. Science, 277(5325). 494-499.

Vysušil, T. (2005). Sociologická reflexe konfliktu mezi společností a prŕrodou. Teoretické př́ístupy a empirická zkoumání. Sociální studia 2 (2). 43-70.

Webb, T.J., Bengston, D.N., Fan, D.P. (2008). Forest value orientations in Australia: An application of computer content analysis. Environmental Management. 41(1) 52-64. 